A few miles east of one of my former homes-the settlemen of Berkeley, in California-there is an isolated peak of moderate beight, from the top of which you may survey an area equal to thit of the State of New York. From Mount Shasta on the north to Mount Whitney on the south, you may trace the jagged, often snow-white, crest which bears the name of Sierra Nevada. Here and there a peak rises a little higher than its neighbours, and can be identified from the look-out; but human vision cannot see the chains beyond the chains, nor the marvellous valley Yosemite and the beautiful Lake Tahoe which are sheltered within the nearest range of hills. All that the eye can distinguish on the horizon are a few of the loftiest summits as it turns toward the east, and a glimpse of the Farallone Islands as it turns toward the west. So to-day, from a hill not very high, we have looked upon a broad area, distinguishing only the chief features of the landscape,-but we have seen the mountains and the sea.

\section{A NEW ISLAND IN THE SOUTH SEAS}

A CCORDING to the Melbourne Argus of December Io, further news respecting the volcanic outbreak which recently occurred in the Friendly Group has been received from Fiji, viâ Auckland. Intelligence concerning it first arrived there by the schooner Midge, from Tonga. Before the vessel arrived, however, the eruption had already reported itself to the eastern portion of the Fiji Group, and the Arsus Correspondent furnishes the following account of it :-

"At Ogea, one of the island outposts lying nearest to the point of eruption, and distant from it about 175 miles in a south-west direction, heavy discharges as of siege artillery were heard on October I4, and continued at short intervals up till the I 7 th. It is to be noted in connection with this that the outbreak occurred, or was first noticed, in Tonga on the reth, and that mention is made of ' a low rumbling noise at intervals during the night.' During the continuance of these heavy discharges, Ogea was frequently and very violently shaken by earthquakes, so that the people were in a state of great consternation. At night-time a lurid glare, as from a great fire, was visible in the direction of Tonga, and these phenomena culminated in a terrific roar on the morning of the $r$ th, such as might be produced by thousands of big guns being discharged simultaneously. Next day a small vessel which had been working the open sea between the Fijian and Friendly Groups, called in to Ogea and reported having passed through vast fields of pumice. This served to confirm the idea generally prevailing that a terrible calamity in the form of a volcanic outbreak had befallen and had overwhelmed Tonga."

The Tonga Correspondent of the Fiji Times, who was an eyewitness of the eruption, has communicated the following account of it to that journal :-

" On the night of Sunday, October II, I885, more than one slight shock of an earthquake was felt, and lightning was seen at intervals at different quarters. Several persons noticed a low rumbling noise at intervals during the night. At sunrise on Monday morning, October 12 , the natives reported that a steamer was coming in. The Tongan Government was induced to send out the schooner Sandfy', and about noon on the day the outbreak was first seen Dr. Buckland, accompanied by the Premier and various officials, started to see the volcanic eruption which it was evident was going on. The Sandfly returned on the 16 th inst. and reported having reached the scene of the eruption on the 13 th, but too late to see much: that on the following morning a small island became for the first time visible, and that the vessel had approached within about a mile of the shore, but a strong current prevented nearer approach. On October I 7 a number of residents chartered Tugi's schooner, and started for the spot, and on the succeeding morning witnesed a spectacle of such surpassing magnificence as men have seldom been permitted to view. An island of, I believe, not less than nine miles superficial area was seen by us, which had been upheaved, presuming the Sandfy's observations to be correct, within four days. On its shore a submarine volcano was belching out a fearful quantity of what I believe to be steam and salt water, throwing it upwards in a column for a distance, I was told by a competent gentleman, of a mile. To give an accurate description in detail of the column and eruption generally is impossible. It is indescribable. The shapes assumed by the steam clouds, after the greatest height had been reached, were inexpressibly beautiful, and were fantastic to a degree. While these clouds were still wreathing and curling, another and another column, with well-defined lines, would shoot upwards, and the downpour of liquid and the wreathing and curling were again and again renewed. The island, named by many 'Fakaogo fei lagi,' or Takaogo Island, is situated about 16 or 20 miles to the northwest of Honga Hapai. I have not a chart to refer to, but believe it is on the site of the Culdibras (?) Reef, marked on the chart, and which is some distance south of Tonga and Kao. Vessels coming here from $\mathrm{Fiji}$ will be able to visit the island without going much from their course. At night time flashes of light are seen, but whether proceeding from flames of volcanic fire or from the electricity generated during the condensation of the volumes of steam, will be best known to scientific people. Many and various are the conjectures as to how the island has been formed, and conjectures alone can be made until the island is visited. The whole matter is likely to create great interest, and will afford an opportunity to scientific people to ascertain, with a tolerable amount of certainty, the exact manner in which these islands of the Pacific have in past ages been produced. The height of the island on the occasion of the visit of the Sandfly was from 20 to 30 feet, and when we saw it on Saturday it appeared to be from 200 to 300 feet."

\section{UNIVERSITY AND EDUCATIONAL INTELLIGENCE}

OXFORD.-Whatever be the fate of the new Moderations Scheme now being considered by a Committee of Congregation, the present academic year will be remarkable for the vigorous onslaught made by the younger Faculties on the time-honoured requirement at Pass Moderations of "a little Latin and less Greek." The waste of a year over classical work having no direct bearing on the final school chosen by the student had become so great a tax on time and patience that, when a blow was at last struck at the evil, but little opposition was expressed in quarters where small sympathy with modern studies was thought to dwell. If the Committee can agree on a working scheme, a great relief will be afforded to students in Natural Science in Oxford.

It is with much pleasure that we notice, after long interval, two Colleges offering Fellowships in Pure Science. Merton offers a Fellowship in Physics, and Lincoln in Biology. Besides these Fellowships, Pembroke has a vacant Medical Fellowship.

The nomination of Examiners in the Honour School of Natural Science (now conducted by a Committee of the Faculty) took place this week. Prof. Burdon-Sanderson succeeds Dr. Gamgee in Physiology, Mr. H. B. Dixon succeeds Mr. Vernon Harcourt in Chemistry, and Mr. J. Walker succeeds Mr. Hayes in Physics.

The following courses of lectures and practical classes will be held during the present term :-

In the Physical Department of the Museum, Prof. Clifton lectures on Electricity, Mr. Walker on Polarised Light, and practical instruction is given by the Professor, Mr. Walker, and Mr. Selby. At Christchurch Mr. Baynes lectures on Thermodynamics, and gives practical instruction in Electrical Measurements. At Balliol Mr. Dixon lectures on Elementary Heat and Light.

In the Chemical Department of the Museum Prof. Odling lectures on the Phenic Compounds; Mr. Fisher continues his course on Inorganic Chemistry, and Dr. Watts continues his course on Organic Chemistry. Practical instruction is given by Messrs. Fisher, Watts, Marsh, and Baker. Practical instruction is also given in the Christchurch and Balliol Laburatories.

In the Morphological Department Prof. Mos-ley lectures on the Anatomy of the Vertebrata; Mr. Spenser has a course on Elementary Animal Morphology; and Mr. Barclay Thompson, on the Osteology and Distribution of the Amphibia and Reptilia. Mr. Arthur Thomson lectures on Human Myology, and has a class for Practical Anatomy. Practical instruction in Comparative Anatomy is given by the Professor, and Messrs. Robertson and Spenser.

In the Pbysiological Department Prof. Burdon-Sanderson lectures on the Physiology of the Nervous System, and will also give twelve elementary lectures during the present and next term on the Vital Phenomena of men and animals. Mr. Dixey lectures and has a class for Practical Histology; Dr. Gotch has a class for Practical Physiology; and Mr. Poulton lectures on the Physiology and Histology of the Special Senses. 